\title{
Real Time PCR Assays for Detection and Quantification of Porcine DNA in Meat Milling Samples
}

\author{
M. Baihaqi ${ }^{1}$, Yuanita Rachmawati2 ${ }^{*}$, Saiku Rokhim ${ }^{2}$, Misbakhul Munir ${ }^{3}$, Lilik Hamidah ${ }^{3}$ \\ ${ }^{1}$ Department of Arabic, Faculty of Tarbiyah, \\ Universitas Islam Negeri Sunan Ampel Surabaya, Indonesia 60237 \\ ${ }^{2}$ Department of Biology, Faculty of Science \& Technology, \\ Universitas Islam Negeri Sunan Ampel Surabaya, Indonesia 60237 \\ ${ }^{3}$ Halal Center University, \\ Universitas Islam Negeri Sunan Ampel Surabaya, Indonesia 60237 \\ \{yuanitarhartono@gmail.com ${ }^{1}$ \}
}

\begin{abstract}
Meat mills in Indonesia are not halal certified. Small traders who do not have a food processor facility will choose the public market. This can be done both by traders who sell halal processed food and processed pork. It is necessary to study the content of meat mills in the public market so that it becomes critical evidence of an institution authorized to issue a policy immediately. This study aims to examine the content of porcine DNA in meat mills in Pasar Surya Kota Surabaya using the Real Time PCR (qPCR) method. QPCR amplification was performed using a porcine probe primer with annealing temperature optimization of $60^{\circ} \mathrm{C}$. The amplification curve shows an increase in the curve in the positive control (EPC) with a value of $\mathrm{Cq} 34.00$, while the negative control (NTC) is not amplified. The results of this study show that 2 out of 10 samples experienced an increase in the amplification curve on the FAM indicator, meaning that in the meat grinding sample there was a content of porcine DNA. The two samples are 8 and 9 with Cq values of 38.02 and 39.04, respectively. Market Halal Certification must be done immediately.
\end{abstract}

Keywords: Meat milling, porcine DNA, Real Time PCR, Halal Certification.

\section{Introduction}

Goods and/or services related to food, beverages, drugs, cosmetics, chemical products, biological products, genetic engineering products, and goods that are used or utilized by the community, especially Muslims, who enter, circulate, and trade in Indonesia must be labeled Halal [1]. This is guaranteed by the Republic of Indonesia Law No. 33 of 2014 concerning Guarantee of Halal Products contained in ayat 4. However, the circulation of food and beverages in the market is often detached from government supervision. Many consumer products and services are circulating without a halal label. One of them is meat grinding services on the public market. The government should certify halal markets before the market operates or map which markets sell illicit goods or halal. Meat milling service on the market is an upstream type that is 
important to note its halalness. Considering that all processed foods may be contaminated with non-halal materials originating from the grinding service.

Allah SWT forbade pork (and including its kind, wild boar) to be used as food clearly stated in His word, the Holy Qur'an in many surat and ayat. 6:145 means "Say: I have not found in the revealed to me that which is forbidden to all who will eat it except the dead or the blood that flows out or pork because truly, each of them is filth or disobedience in the form of slaughter for besides Allah. Unless anyone is forced to do it not because they want it and not because of violation (the limit), then truly, your Lord is Forgiving, Most Merciful ". This Al An'am surat in ayat 145 explains very clearly that pork is forbidden by Allah to be used as food.

Molecular technology can be used as an accurate alternative solution to authenticate/ ascertain whether a food sample contains pork contaminants, judging from the DNA content [2]. This technology is very possible to ascertain whether a food sample contains porcine contaminants, although in small amounts [1]. This is because pork or wild boar are usually sold with mixed beef or other halal meat, as processed foods such as meatballs, sausages, nuggets using milling machines on the market. Molecular technology that can be used as a method of identifying pork/wild boar contaminants in meat and processed food quickly/rapid test is PCR technique. Both conventional PCR, Multiplex PCR, and the latest are Real Time PCR.

Alaraidh [3] used PCR technology to amplify pig DNA using a specific primer of pig DNA, in the testing of imported meat contaminants on the Saudi Arabia market. Murugaiah, C. et al., [4], with a study entitled using specific Mitochondrial DNA to identify processed foods contaminated with pork. Erwanto, Y. et al. [5] in 2014 conducted a study entitled "Identification of Pork Contamination in Local Meatballs of Indonesia Using Polymerase Chain ReactionRestriction Fragment Length Polymorphism (PCR-RFLP) Analysis". This research was conducted by researchers at the Gadjah Mada University in Yogyakarta, using the RFLP PCR technique to analyze processed meat foods in the form of meatballs in traditional markets in Indonesia. Tanabe, S. et al. [6], [7] used PCR technology to amplify pig DNA using specific primers of pig DNA, in the testing of processed food allergen contaminants in Japan. Recent molecular technology to detect the presence of contaminants of pig/wild boar DNA in meat and processed meat products is using Real Time PCR technology [1], [8], [9], [10].

\section{Material and Methods}

This type of research is quantitative descriptive. The research was conducted in September 2018 until January 2019. The study was conducted by taking samples at the Surabaya City Market Regional meat mill. Laboratory tests were carried out in the Integrated Laboratory (Genetic and Tissue Culture) of UIN Sunan Ampel Surabaya for DNA extraction and then continued with the Real Time PCR method. The sampling technique in this study is a non probability purposive sampling. In this case, samples are taken from meat mills from the Surya Market in Surabaya, where there are meat mills and close to the seller of processed pork.

The materials and tools used in this study were 10 samples from meat mills from the Surya City of Surabaya Market. DNA isolation kit (Instagene Matrix), Kit (Progenus EasyfastTM Porcine / Suidae Detection \& Quantification Kit), MIX (Primary, probe and reagent Real Time PCR), NTC (negative control), EPC (external positive control), ddH2O (aqua bidest ), and tissue. UV DNA (Biodrop) spectrophotometer, and Real Time PCR thermal cycler (Bio-Rad CFX96).

Reagent qPCR is $9 \mu 1$ of Mix solution. Then a $1 \mu \mathrm{lDNA}$ template is added to the mastermix. This is also done for the NTC as a negative control and EPC solution as a positive control. The following Table 1. is an optimization table for the Real Time PCR stage. 
Table 1. Temperature Optimization on Real Time PCR.

\begin{tabular}{lccc}
\hline \multicolumn{1}{c}{ Step } & Time & Temperature & Number Of Cycles \\
\hline 1-Activation Step & $2 \mathrm{~min}$ & $50^{\circ} \mathrm{C}$ & 1 \\
2-Initial Denaturation Step & $3 \mathrm{~min}$ & $95^{\circ} \mathrm{C}$ & 1 \\
Denaturation & $10 \mathrm{sec}$ & $95^{\circ} \mathrm{C}$ & 40 \\
Annealing-Extention & $1 \mathrm{~min}$ & $60^{\circ} \mathrm{C}$ & \\
\hline
\end{tabular}

Data processing was carried out in a quantitative descriptive manner by looking at the absorbance of DNA at wavelength $\lambda 260 \mathrm{~nm}$ with a purity ratio and comparison of absorbance values $\AA 260$ / $\AA 280 \mathrm{~nm}$ in the range of values of 1.8-2.0. Analysis of Real Time PCR (qPCR) data is done by using the software program Biorad CFX manager.

\section{Results and Discussion}

The Real Time PCR method is the most accurate and efficient current method used to detect the presence of DNA more specifically [11], [12], [13], [14], [15], [16], [17]. In this study, Real Time PCR method was used to detect the presence of DNA contaminants in meat milling samples in the Surya market of Surabaya City. In this chapter, we will explain the general conditions of the study, the analysis of DNA purity and concentration, amplification of sample DNA milling with Real Time PCR (qPCR), and general discussions that are described descriptively in the form of tables and images.

\subsection{Isolation DNA Result}

The results of DNA isolation are well supported by the results of the quality (purity) and quantity (concentration) of the DNA extract obtained. The DNA concentration and purity were analyzed using a UV / VIS DNA (Biodrop) spectrophotometer. The purity of DNA can be measured by calculating the absorbance value of $\lambda 260$ divided by the absorbance value $\lambda 280$ $\mathrm{nm}(\hat{2} 260$ / 280) and the purity ranges from 1.8-2.0. Table 1 below show Concentration and Purity Ratio of DNA.

Table 1. Concentration and Purity Ratio of DNA

\begin{tabular}{|c|c|c|c|c|c|c|}
\hline \multirow{2}{*}{$\begin{array}{l}\text { Sample } \\
\text { Code }\end{array}$} & \multicolumn{4}{|c|}{ Absorbance (nm) } & \multirow{2}{*}{$\begin{array}{l}\text { Concentration } \\
(\mu \mathrm{g} / \mathrm{ml})\end{array}$} & \multirow{2}{*}{$\begin{array}{c}\text { Purity Ratio } \\
(\AA \AA 260 / \AA ̊ 280)\end{array}$} \\
\hline & $\AA 230$ & $\AA \dot{2} 260$ & $\AA \dot{2} 280$ & $\AA \dot{3} 320$ & & \\
\hline 1 & 1,036 & 0,737 & 0,400 & 0,085 & 32,60 & 2,070 \\
\hline 2 & 0,429 & 0,249 & 0,134 & 0,031 & 10,90 & 2,117 \\
\hline 3 & 0,581 & 0,268 & 0,136 & 0,035 & 11,65 & 2,308 \\
\hline 4 & 1,182 & 0,692 & 0,320 & 0,106 & 29,31 & 2,736 \\
\hline 5 & 1,131 & 0,610 & 0,296 & 0,100 & 25,52 & 2,598 \\
\hline 6 & 0,777 & 0,394 & 0,168 & 0,027 & 18,34 & 2,606 \\
\hline 7 & 0,736 & 0,394 & 0,168 & 0,027 & 19,57 & 2,655 \\
\hline 8 & 0,685 & 0,389 & 0,163 & 0,037 & 17,59 & 2,796 \\
\hline 9 & 0,776 & 0,529 & 0,207 & 0,038 & 24,57 & 2,900 \\
\hline 10 & 0,902 & 0,560 & 0,244 & 0,038 & 26,11 & 2,532 \\
\hline
\end{tabular}

The concentration obtained from the analysis of DNA isolates by UV DNA spectrophotometry has a high average value. This is because the sample used is a sample of meat milling. Meat has a large number of cells so that the DNA concentration produced is high. 
In the measurement of DNA purity, the ratio $\AA 260$ / 280 with a value lower than 1.8 will indicate the presence of contamination from phenol, whereas the absorbance value of A230 nm indicates contamination originating from peptide bonds. Contamination by proteins comes from cell components that are not lysed during the process of DNA extraction, besides that it can be derived from phenol as one of the materials used in the process of isolation for DNA precipitation. If the ratio obtained at $60260 / 280$ exceeds 2.0 then the DNA used still contains contaminants from membrane proteins and the presence of contamination of heavy compounds of small molecules such as RNA or other compounds so that the DNA obtained is not pure.

\subsection{Real Time PCR Result}

The result of DNA extraction obtained was then used as a template for the next stage, namely amplification using Real Time PCR (qPCR). Before the qPCR process takes place, DNA dilution needs to be done first to minimize contamination such as phenol, protein, and the remnants of material at the time of extraction. In addition to minimizing contamination, DNA dilution functions to determine the final volume of DNA so that the resulting amplification curve is optimal. The amplification curve is considered optimal if the curve does not reach the plateu phase early in the cycle. Table 2. Show Real Time PCR result in term of Cq Values. N/A mean not amplified, FAM for porcine detection indicator, while VIC for vertebrate detection indicator.

Table 2. Cq Values of Meat Mill Samples

\begin{tabular}{ccc}
\hline Sample Code & \multicolumn{2}{c}{ Cq Values } \\
\cline { 2 - 3 } & FAM & VIC \\
\hline 1 & N/A & 24,42 \\
\hline 2 & N/A & 32,50 \\
\hline 3 & N/A & 29,32 \\
\hline 4 & N/A & 25,30 \\
\hline 5 & N/A & 30,29 \\
\hline 6 & N/A & 29,46 \\
\hline 7 & N/A & 26,58 \\
\hline 8 & 38,02 & 21,97 \\
\hline 9 & 39,04 & 21,80 \\
\hline 10 & N/A & 26,36
\end{tabular}

Real Time PCR uses fluorescence dyes and fluorescence probes [8], [12]. In this study, a fluorescence hydrolysis probe (TaqMan probe) was used using specific oligonucleotides which complement the DNA to be amplified. Fluorescent hydrolysis probes will glow when reporters and quenchers separate through hydrolysis due to nuclease activity. Hydrolysis probes work specifically and can prevent the occurrence of primers-dimers and mis-priming so that they cause non-specific amplification products. Table 2 show that there was Cq Values in sample 8 and 9 in FAM column. FAM is used for porcine detection indicator. While samples number $1,2,3,4,5,6,7$, and 10 were N/A mean not amplified. VIC which is used for vertebrate detection indicator are shown by all of samples. So, all of samples are contain vertebrate meat, but only samples 8 and 9 contain porcine DNA

Real Time PCR results are shown in Figure 1 below. From each amplification graph displayed, there are External Positive Control (EPC), No Template Control (NTC) as negative controls, Threshold Cycle (Ct), and 1 sample. The increase in the green curve (VIC) indicates the presence of the content of vertebrate animal groups in the sample. The increase in the blue curve (FAM) indicates the sample contains pork. 
(1)

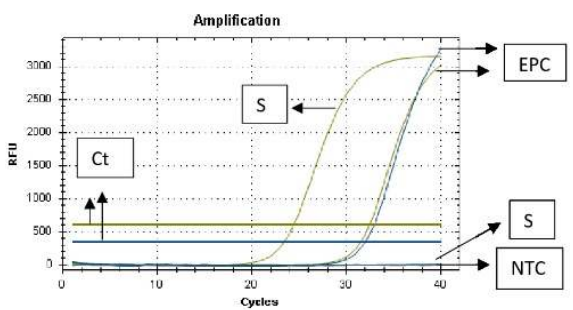

(3)
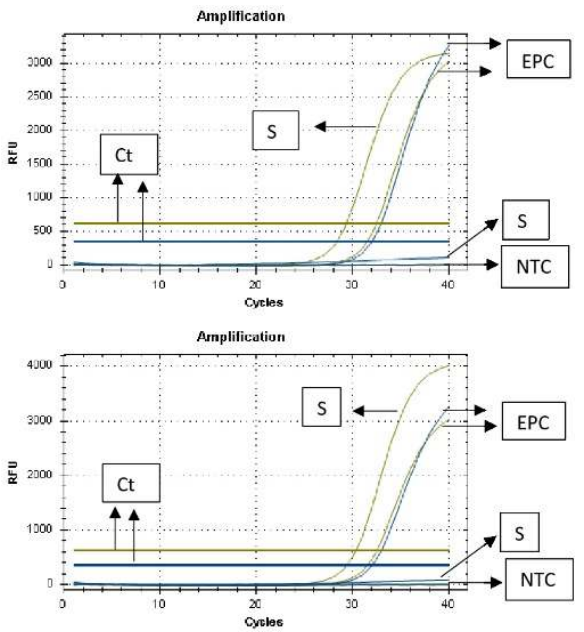

(5)

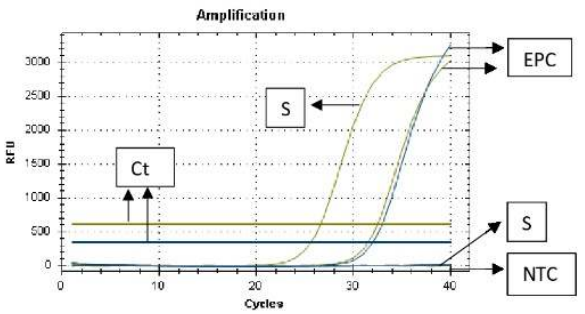

(7)

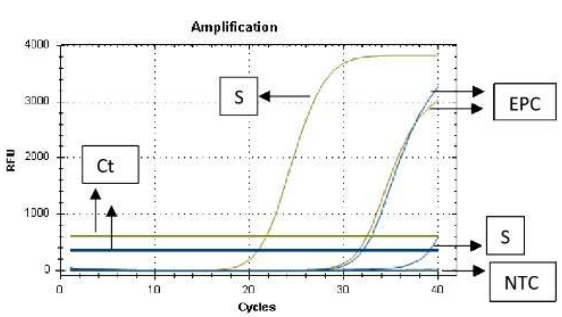

(9)

Fig. 1. Real Time PCR Result in Diagram of DNA Amplification Curve Samples Number 1-10. Description: VIC are shown in green color, FAM in blue. EPC (External Positive Control), NTC (No Template Control), Ct (Threshold Cycle), S (Sample)

Based on the image above, samples of meat milling 8 and 9 show a significant increase in the curve on VIC (indicator of vertebrate detection). Besides VIC detection, there was a

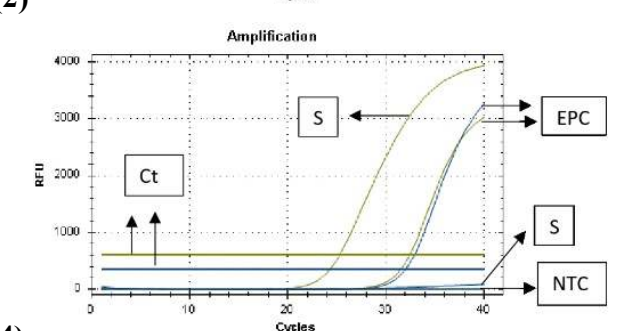

(4)
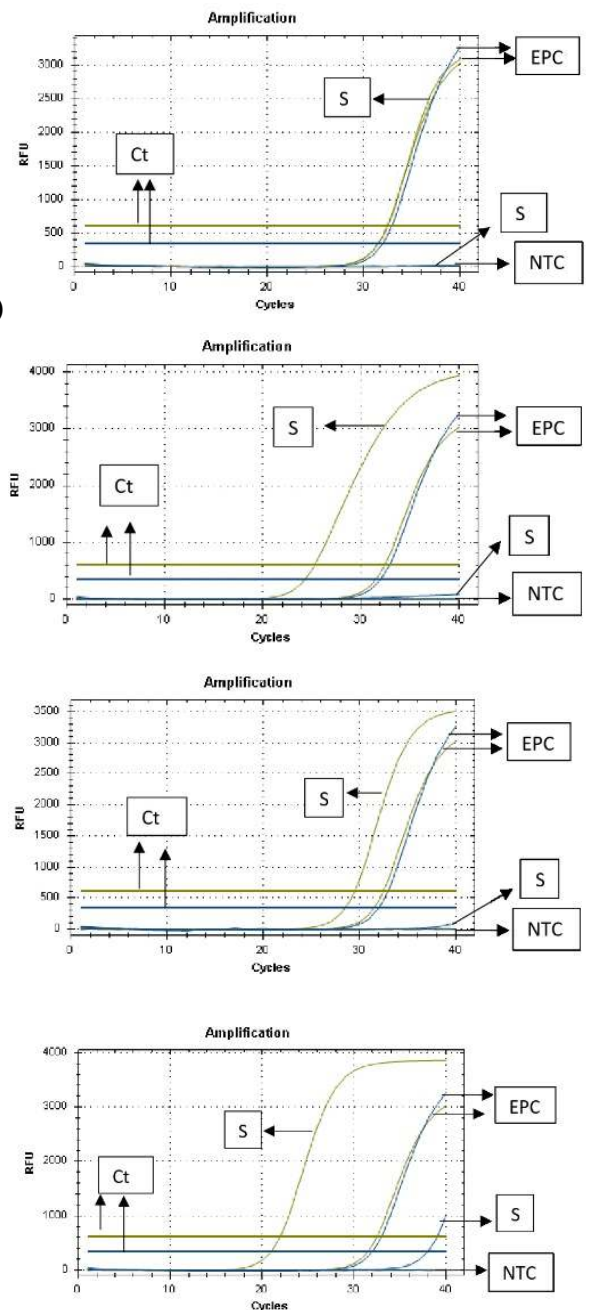

(8)

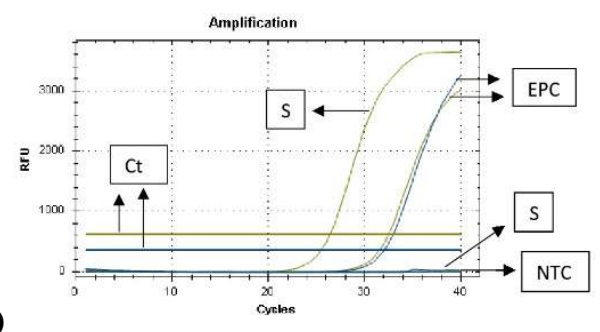

(10) 
significant increase in FAM detection (pig detection indicator). This shows that the tested DNA contained vertebrate animals in it and positive for pigs. The higher the value of $\mathrm{Cq}$ the lower the curve produced. This happens because the value is close to the positive control (EPC) amplified with a value of 32.00. Both FAM and VIC values are considered valid if the Threshold cycle $(\mathrm{Ct})$ is for positive control with a value of approximately 30.00. Sample number $1,2,3,4,5,6,7$, and 10 are not contaminated by porcine DNA. The two samples are 8 and 9 with Cq values of 38.02 and 39.04, respectively, experiencing an increase in the amplification curve on the FAM indicator, meaning that in the meat mill samples there was a content of porcine DNA.

Real Time PCR has the working principle of detecting and quantifying fluorescent reporters. Fluorescent signals will increase with increasing DNA amplification products in the reaction. Reactions during the exponential phase can be monitored by viewing and recording the amount of fluorescent emissions in each cycle. The increase in the amplification curve at the exponential phase is closely related to the number of initiations of the target gene. Therefore, the higher the target gene expression level, the faster the detection of fluorescent emissions occurs.

\section{Conclusion}

The amplification curve shows an increase in the curve in the positive control (EPC) with a value of Cq 34.00, while the negative control (NTC) is not amplified. Of the 10 samples, 2 are indicated the content of porcine DNA. Experiencing an increase in the amplification curve on the FAM indicator, meaning that in the meat grinding sample there was a content of porcine DNA. The two samples are 8 and 9 with $\mathrm{Cq}$ values of 38.02 and 39.04, respectively. Market Halal Certification must be done immediately. The government needs to carry out tighter monitoring from upstream to downstream food and service products so that no consumers are harmed. Remembering Halal is a very sensitive issue in a country with the largest Muslim population in the world, and because halal is a must.

\section{Acknowledgements}

This research was supported by Lembaga Penelitian dan Pengabdian Masyarakat LPPM Universitas Islam Negeri Sunan Ampel Surabaya. We thank our colleagues from PT Sciencewerke who provided insight and expertise that greatly assisted the research.

\section{References}

[1] Rachmawati, Y., Rokhim, S., Munir, M., \& Agustina, E.: Deteksi Kontaminan Fragmen DNA Pengkode cyt b Babi pada Sampel Softgellcandy Tak Berlabel Halal. Indonesia Journal of Halal, 1(1), 25-30. DOI: 10.14710/halal.v1i1.3115 (2018)

[2] Rachmawati, Y.: Karakter Fenotip dan Molekular Melon (Cucumis melo L. "Tacapa") pada Media Tanam Tanah Karst. Tesis Universitas Gadjah Mada Yogyakarta. (2014)

[3] Alaridh, I.A.: Improved DNA Extraction Method for Porcine Contaminants, Detection in Imported Meat to The Saudi Market. Saudi Journal of Biological Sciences, Vol.15 No.(2), pp: 225-229 (2008)

[4] Murugaiah, C., Noor, Z.M., Mastakim, M., Bilung, L.M., Selamat, J., Radu, S.: Meat Species Identification and Halal Authentication Analysis using Mitochondrial DNA. Meat Science, Vol. 83, pp: 57-61. (2009)

[5] Erwanto, Y., Abidin, M.Z., Muslim, E.Y., Sugiyono, \& Rohman, A.: Identification of Pork Contamination in Meatballs of Indonesia Local Market Using Polymerase Chain Reaction- 
Restriction Fragment Length Polymorphism (PCR-RFLP) Analysis. Asian Australas. J. Anim. Sci., Vol.. 27 No.10, pp: 1487-1492. (2014)

[6] Tanabe, S., Miyauchi, E., Muneshige, A., Mio, K., Sato, C., \& Sato, M.: PCR Method of Detecting Pork in Foods for Verifying Allergen Labeling and for Identifying Hidden Pork Ingredients in Processed Foods. Biosci. Biotechnol. Biochem., Vol.71 No.7, pp: 1663-1667. (2007)

[7] Tanabe, S., Hase, M., Yano, T., Sato, M., Fujimura, T., \& Akiyama, H.: A Real-Time Quantitative PCR detection Method for Pork, Chicken, Beef, Mutton, and Horseflesh in Foods. Biosci. Biotechnol. Biochem., Vol.71 No.12, pp: 3131-3135. (2007)

[8] Kim, M., Yoo, I., Lee, S.Y., Hong, Y., Kim, H.Y.: Quantitative detection of pork in commercial meat products by TaqMan Real-Time PCR assay targeting the mitochondrial D-loop region. Food Chemistry 210 102-106. DOI: 10.1016/j.foodchem.2016.04.084. (2016)

[9] Rahmati S., Julkapli N.M., Yehye W.A. \& Basirun W.J.: Identification of meat origin in food products-A review. Food Control. DOI: 10.1016/j.foodcont.2016.04.013. (2016)

[10] Shabani, H., Mehdizadeh, M., Mousavi, S.M., Dezfouli, E.A., Solgi, T., Khodaverdi, M., Rabiei, M., Rastegar, H., Alebouyeh, M.: Halal authenticity of gelatin using species-specific PCR. Food Chemistry 184 203-206. DOI: 10.1016/j.foodchem.2015.02.140. (2015)

[11] Amqizal, H.I.A., Al-Kahtani, H.A., Ismail, E.A., Hayat, K., Jaswir, I.: Identification and verification of porcine DNA in commercial gelatin and gelatin containing processed foods. Food Control. DOI: 10.1016/j.foodcont.2017.02.024. (2017)

[12] Cai, H., Gu, X., Scanlan, M.S., Ramatlapeng, D.H., Lively, C.R.: Real-time PCR assays for detection and quantitation of porcine and bovine DNA in gelatin mixtures and gelatin capsules. Journal of Food Composition and Analysis 25 83-87. DOI: 10.1016/j.jfca.2011.06.008. (2012)

[13] Sultana, S., Hossain, M.A.M., Zaidul, I.S.M., Ali, M.E.: Multiplex PCR todiscriminate bovine, porcine, and fish DNA in gelatin and confectionery products, LWT. Food Science and Technology DOI: 10.1016/j.lwt.2018.02.019. (2018)

[14] Ballin, N.Z.: Authentication of meat and meat products. Meat Science 86 577-587. DOI: 10.1016/j.meatsci.2010.06.001. (2010)

[15] Demirhan, Y., Ulca, P., Senyuva, H.Z.: Detection of porcine DNA in gelatine and gelatinecontaining processed food products-Halal/Kosher authentication. Meat Science 90 686-689. DOI: 10.1016/j.meatsci.2011.10.014. (2012)

[16] Soares, S., Amaral, J.S., Beatriz, M.P.P., Oliveira, Mafra, I.: A SYBR Green real-time PCR assay to detect and quantify pork meat in processed poultry meat products. Meat Science 94 115-120. DOI: 10.1016/j.meatsci.2012.12.012. (2013)

[17] Fajardo, V., Gonzalez, I., Rojas, M., Garcia, T., Martın, R.: A review of current PCR-based methodologies for the authentication of meats from game animal species. Trends in Food Science \& Technology 21 408-421. DOI: 10.1016/j.tifs.2010.06.002. (2010) 